DOI: https://doi.org/10.15407/techned2018.05 $: 092$

\title{
MULTIFUNCTIONAL CONVERTER FOR SINGLE-PHASE COMBINED POWER SUPPLY SYSTEMS FOR LOCAL OBJECTS WITH A PHOTOVOLTAIC SOLAR BATTERY
}

Journal

Publisher

ISSN

Issue

Pages
Tekhnichna elektrodynamika

Institute of Electrodynamics National Academy of Science of Ukraine 1607-7970 (print), 2218-1903 (online)

No 5, 2018 (September/October)

$92-95$

\section{Authors}

\section{A. Shavelkin, I. Shvedchykova}

Kyiv National University of Technologies and Design, str. Nemirovich-Danchenko, 2, Kyiv, 01011, Ukraine, e-mail: shavolkin@gmail.com

The paper deals with the single-phase converter for combined power supply systems with a built-in transformer and inverter for volt-add, that combines the function of a power active filter with the maintenance of a power factor close to unity when it is operating in parallel with a grid and also the operation in an autonomous mode and voltage stabilization of the load in the normally acceptable range of value. The choice of the circuit parameters is confirmed. It is proposed to use the variable structure of the converter control system with regulation of voltage at the input of a grid inverter in accordance with the value of a grid voltage and cut-off energy generation to the grid when its voltage is higher than the maximum acceptable value. The results of the system simulation are presented. References 4, figures 3. 
Key words: combined power supply system, power active filter, photovoltaic solar battery, current controlled voltage source inverter, transformer and inverter for volt-add, autonomous mode, stabilization of voltage, simulation.

Received: 05.03.2018

Accepted: 11.04 .2018

Published: 16.08 .2018

\section{References}

1. Sung-Hun Ko, Seong-Ryong Lee, Hooman Dehbonei, Nayar C.V. A Grid-Connected Photovoltaic System with Direct Coupled Power Quality Control. $32^{\text {nd }}$ Annual Conference on IEEE Industrial Electronics , IECON 2006, Paris, France, 6-10 Nov., 2006. Pp. 5203-5208.

2. Tsao-Tsung Ma. Power Quality Enhancement in Micro-grids Using Multifunctional DG Inverters. Proceedings of the International MultiConference of Engineers and Computer Scientists ， IMECS 2012. Hong Kong, 2012. Vol II. Pp. 996-1001.

3. Shavelkin A.A. Structures of single-phase converters units for combined electrical supply systems with photoelectric solar panels. Tekhnichna Elektrodynamika. № 2. 2018. Pp. 39-46. (Rus)

4. ABB solar inverters. www.abb.com/solarinverters 